\title{
Reproductive cycle in an imposex-affected population of Olivancillaria deshayesiana (Gastropoda: Olividae) from Mar del Plata, Argentina
}

\author{
Valeria Teso $^{1, *}$, Florencia Arrighetti ${ }^{2}$, Pablo E. Penchaszadeh ${ }^{1}$ \\ ${ }^{1}$ CONICET - Museo Argentino de Ciencias Naturales, Av. Angel Gallardo 470, Lab. 57, \\ C1405DJR Buenos Aires, Argentina \\ ${ }^{2}$ CONICET - Laboratorio de Biología de Invertebrados Marinos, DBBE, Facultad de Ciencias Exactas y Naturales, \\ Universidad de Buenos Aires, 1428 Buenos Aires, Argentina
}

\begin{abstract}
Olivancillaria deshayesiana (Gastropoda: Olividae) is distributed from Ilha Grande (Rio de Janeiro, Brazil) to Necochea (Buenos Aires, Argentina). Apart from some descriptions of the embryonic development and the egg capsules, little is known about the reproduction and ecology of this species. In this 2 yr study (October 2005 to September 2007), the reproductive cycle of $O$. deshayesiana was examined in a population highly affected by imposex, from the Mar del Plata coast, Argentina. Males exhibited seasonal reproductive activity, with a major spawning period from September to January (spring to early summer) for the $2 \mathrm{yr}$, which coincided with an increase in seawater temperature and photoperiod. In contrast, females were mature and capable of spawning year round, with a major spawning period from September to January (spring to early summer), simultaneous with the major spawning period of males.
\end{abstract}

KEY WORDS: Imposex $\cdot$ Mar del Plata $\cdot$ Olivancillaria $\cdot$ Olividae $\cdot$ Reproduction

\section{INTRODUCTION}

The neogastropod genus Olivancillaria d'Orbigny, 1840 includes soft-bottom species that inhabit shallow waters up to $70 \mathrm{~m}$ depth in the Argentine Malacological Province (AMP), extending from Bahia state, Brazil $\left(12^{\circ} 15^{\prime} \mathrm{S}, 37^{\circ} 47^{\prime} \mathrm{W}\right)$ to Punta Pardelas $\left(42^{\circ} 37^{\prime} \mathrm{S}, 64^{\circ} 15^{\prime} \mathrm{W}\right)$, Chubut province, Argentina (Teso \& Pastorino 2011). Eight Olivancillaria species inhabit the southwestern Atlantic (Teso \& Pastorino 2011), some of which are the target of subsistence fisheries (Scelzo et al. 2002, Narvarte 2006). This genus and some volutids (i.e. Adelomelon, Zidona) and nassarids (i.e. Buccinanops) represent the most important endemic and abundant gastropods on sandy bottoms in the AMP.

Olivancillaria deshayesiana is commonly found from Ilha Grande ( $\left.23^{\circ} 09^{\prime} \mathrm{S}, 44^{\circ} 13^{\prime} \mathrm{W}\right)$, Rio de Janeiro state, Brazil, to Necochea $\left(38^{\circ} 33^{\prime} \mathrm{S}, 58^{\circ} 44^{\prime} \mathrm{W}\right)$, Bue- nos Aires province, Argentina, up to $60 \mathrm{~m}$ depth (Teso \& Pastorino 2011). Individuals are semi-buried, and their shell is partially covered by the mantle. Little is known about the reproduction and ecology of this species. Borzone (1995) described the embryonic development and the egg capsules of $O$. deshayesia$n a$, which are attached to the shells of other live gastropods (i.e. Buccinanops monilifer and B. duartei); a single embryo hatches from each egg capsule (Borzone 1995). O. deshayesiana is a bycatch of the fisheries for the prawn Artemesia longinaris and the shrimp Pleoticus muelleri (Scelzo et al. 2002), rather than being a direct target of artisanal fishermen. Recently, Teso \& Penchaszadeh (2009) reported the occurrence of imposex (masculinization of females caused by the presence of tributyltin [TBT] in the water) in an $O$. deshayesiana population from the Mar del Plata area, and Arrighetti et al. (2012) determined through a von Bertalanffy growth model that 
this species may grow to a total shell length of $31 \mathrm{~mm}$ in about $10 \mathrm{yr}$. The aim of our study was to describe the gonadal structure and reproductive cycle of $O$. deshayesiana, and to provide new information on the occurrence of imposex in a population in the Mar del Plata area, Argentina.

\section{MATERIALS AND METHODS}

\section{Sampling}

Mar del Plata $\left(38^{\circ} 20^{\prime} \mathrm{S}, 57^{\circ} 37^{\prime} \mathrm{W}\right)$ is an open coast and the site of the most important coastal fishery fleet of Argentina (Penchaszadeh et al. 2001). In this area, water temperature ranges seasonally between 8.4 and $20.8^{\circ} \mathrm{C}$ and salinity is rather constant at $33.8 \%$ (www.iafe.uba.ar/tele/Antares_argentina/; Guerrero \& Piola 1997).

Specimens of Olivancillaria deshayesiana were collected monthly by bottom trawling $(3 \mathrm{~m}$ mouth opening, $15 \mathrm{~mm}$ mesh size) off Mar del Plata City between 5 and 12 m deep from October 2005 to September 2007. Approximately 20 snails were caught each month and taken to the laboratory, where the shell was separated from the soft body. Shell length (SL) was measured with a Vernier caliper to the nearest $1 \mathrm{~mm}$, and the shell-free wet mass (SFWM) was weighed to the nearest $0.1 \mathrm{~g}$. To establish the morphometric relationship between SL and SFWM for each sex, linear regression analyses were performed using $\log (\mathrm{SFWM})=\log (a)+b \times \log (\mathrm{SL})$. Parallelism tests and analysis of covariance (ANCOVA) were performed to compare the relationship between SFWM and SL between sexes (Sokal \& Rohlf 1995). A chi-squared test was used to test for significant differences in sex ratio. Statistical analysis was carried out with the software Statistica v. 6.0.

Recently, Teso \& Penchaszadeh (2009) reported that this population is affected by imposex, and on this account animals were sexed by differences in gonad color and the presence (females) or absence (males) of internal sexual glands such as capsule and albumen glands. Sex was confirmed by the histological examination of gonad sections under a Zeiss Axio
Imager Z1 microscope. The frequency of imposex was calculated as the proportion of females with imposex compared to the total number of females in the sample. The following values were calculated: mean female penis length, mean male penis length, and relative penis size index (RPSI), defined as (mean length of female penis) ${ }^{3} /$ (mean length of male penis $)^{3} \times 100$ (Gibbs \& Bryan 1994).

\section{Gonadal structure and reproductive cycle}

The gonads of each individual were fixed in Bouin's solution, dehydrated in a graded ethanol series $(70$, 80,96 , and $100 \%$ ), embedded in paraffin and resin, cut at $5 \mu \mathrm{m}$ thickness, and stained with Harris' hematoxylin and eosin. Gonad sections were examined histologically under a Zeiss Axio Imager Z1 microscope and photographed with an SV Micro-SoundVision digital camera. To study oocyte growth, the mean of 2 oocyte diameter measurements (taken at right angles to each other) was calculated for 15 to 35 oocytes containing a nucleus with nucleolus, from each female. In addition, the different stages of gonadal development were analyzed for both sexes.

\section{RESULTS}

Sex could be distinguished in 470 snails. The overall sex ratio of 1:1.4 (female:male) differed significantly from 1:1 $\left(\chi^{2}=7.53, \mathrm{df}=1, \mathrm{p}<0.01\right)$. Total SL ranged from 16 to $33.3 \mathrm{~mm}$ in females and from 19.5 to $35 \mathrm{~mm}$ in males. The relationships between total SL and total SFWM are shown in Table 1. The parallelism test revealed a statistically significant difference between sexes $(F=312.8$, p $<0.01)$, with males being significantly larger than females (parallelism test, $\mathrm{p}<0.01$ ).

The incidence of imposex-affected females of Olivancillaria deshayesiana was $81.9 \%$, and the mean RPSI was 3.56. Most of them had a single vas deferens and penis (Fig. 1a,c), and the remaining individuals $(3.6 \%)$ presented malformations such as 2 penises (Fig. 1b). None of the imposexed females had a vas deferens obstructing the vagina.

Table 1. Olivancillaria deshayesiana. Relationship between shell length (SL) and shell-free wet mass (SFWM) for males and females. Values are $\pm \mathrm{SD}$

\begin{tabular}{|lccccc|}
\hline Sex & Mean SL $(\mathrm{mm})$ & Mean SFWM $(\mathrm{g})$ & Regression equation & $\mathrm{R}^{2}$ & $\mathrm{p}$ \\
\hline Male & $28.3 \pm 2.6$ & $3.0 \pm 1.4$ & $\log (\mathrm{SFWM})=3.24 \times \log (\mathrm{SL})-5.23$ & 0.76 & $<0.01$ \\
Female & $26.9 \pm 2.6$ & $2.3 \pm 0.8$ & $\log (\mathrm{SFWM})=3.24 \times \log (\mathrm{SL})-4.26$ & 0.78 & $<0.01$ \\
\hline
\end{tabular}




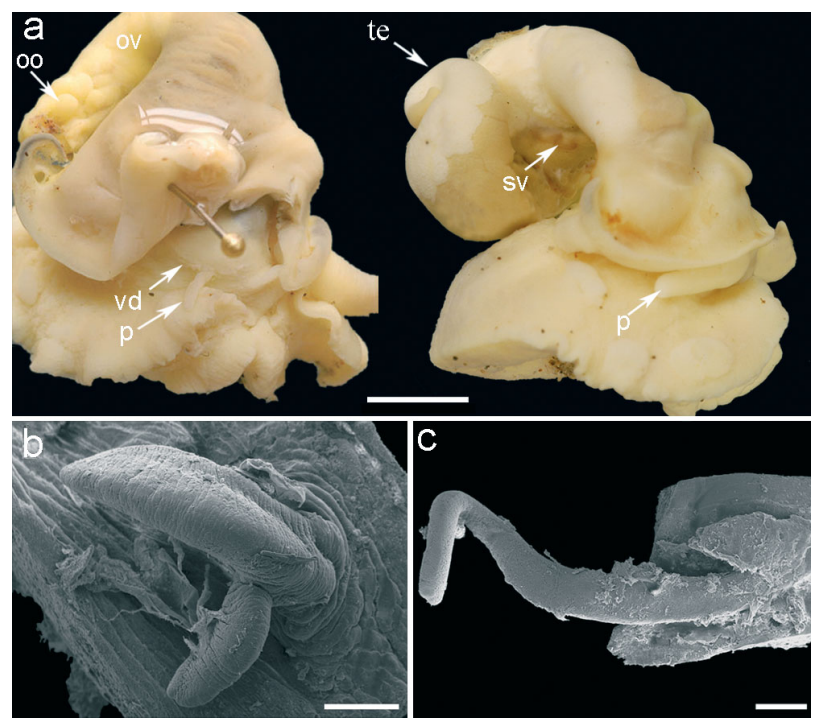

Fig. 1. Olivancillaria deshayesiana. (a) Female (left) with vas deferens (vd) and penis (p); note the presence of numerous oocytes (oo) in the ovary (ov). Male (right) with a normal penis (p); te: testicle, sv: seminal vesicle. Scale bar $=5 \mathrm{~mm}$. (b) Scanning electron microscopy (SEM) image of a female with multiple penises. Scale bar $=200 \mu \mathrm{m}$. (c) SEM image showing detail of a female penis. Scale bar $=1 \mathrm{~mm}$
Based on histological observations, the male gametogenic cycle was divided into 4 developmental stages: proliferation and growth, pre-evacuation, evacuation, and resorption. The stage of proliferation and growth was characterized by the presence of spermatocytes and spermatogonia near the tubule walls (Fig. 2a); spermatids were also found, and the lumina of the spermatogenic tubules and the seminal vesicle were empty. In the pre-evacuation stage, spermatozoa were placed in the center of the tubule lumen (Fig. 2b); spermatogonia, spermatocytes, and spermatids were located near the tubule walls, and the seminal vesicle was empty. In the evacuation stage, the lumina of the tubules and the seminal vesicle were full of spermatozoa (Fig. 2c). The resorption stage was characterized by the complete absence of spermatozoa, with the spermatogenic tubules and seminal vesicle appearing collapsed (Fig. 2d); yellow bodies and signs of degradation were found.

The monthly frequency of males in each developmental stage is summarized in Fig. 3. Males at the stage of proliferation and growth were found between May and September, reaching a maximum number between May and June (autumn) of the second year. The pre-evacuation stage took place be-

\section{Gonadal structure and reproductive cycle}

In both sexes, gonads were located distally in the visceral mass, intruding into the digestive gland. This made it impossible to calculate the gonadosomatic index (see Figs. 1a, 2d, 5a).

\section{Males}

The male gonad extended from the apex to almost the end of the body whorl (Fig. 1a, right). The testis was conspicuous, varying from dark brown and branched (resorption stage) to cream (ripe stage). The seminal vesicle was light brown, inconspicuous, and contiguous to the testis, embedded in it. In histological sections, the testis consisted of numerous spermatogenic tubules separated from each other by connective tissue (Fig. 2). Spermatogenesis occurred within the spermatogenic tubules, each of which was surrounded by a membrane (Fig. 2).
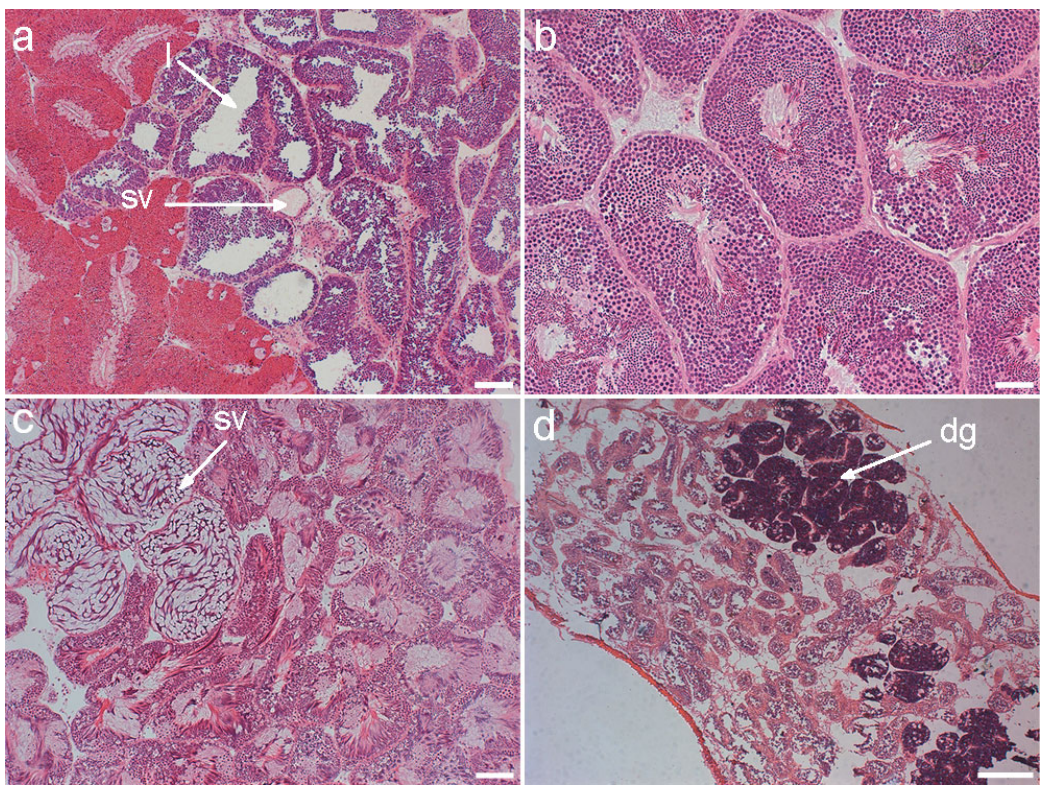

Fig. 2. Olivancillaria deshayesiana. Histology of male gonad at different developmental stages. (a) Proliferation and growth: tubules filled with spermatogonia and spermatocytes; no spermatids or spermatozoa were observed. The lumina (l) of the spermatogenic tubules and seminal vesicle (sv) are empty. (b) Pre-evacuation: spermatogenic tubules with the entire spermatic series. (c) Evacuation: spermatogenic tubule full of spermatozoa, note the seminal vesicle (sv) full of spermatozoa. (d) Resorption: degrading spermatozoa free in the testis; dg: digestive gland. Scale bars $=200 \mu \mathrm{m}(\mathrm{a})$; $100 \mu \mathrm{m}(\mathrm{b}, \mathrm{c}) ; 300 \mu \mathrm{m}(\mathrm{d})$ 


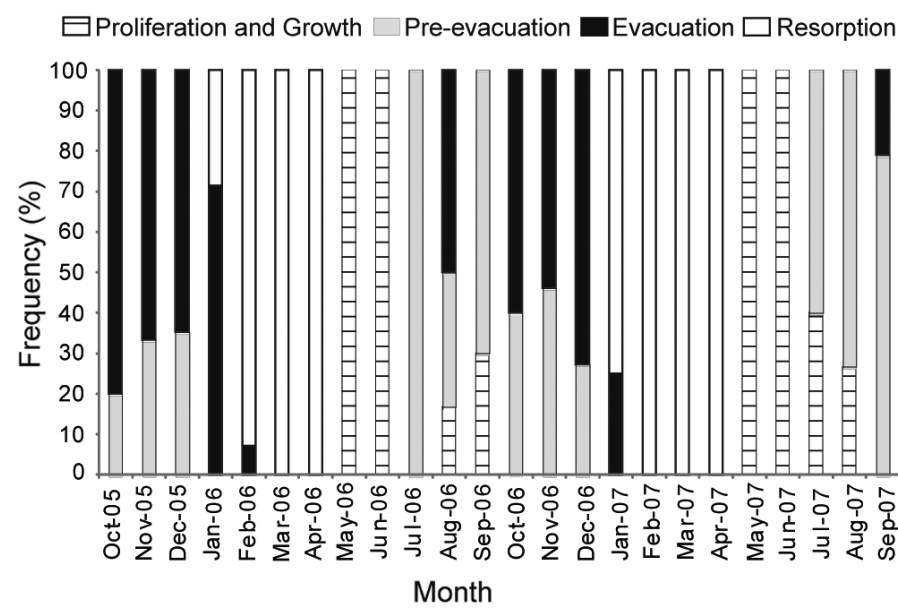

Fig. 3. Olivancillaria deshayesiana. Monthly frequency of different gonad developmental stages of males for the study period (October 2005 to September 2007)

tween July and December (winter to spring); spermatozoa were released from the gonads between September and January (spring to early summer), simultaneously with an increase in surface water temperature and photoperiod (Fig. 4). The resorption stage occurred between January and April, with a maximum proportion of individuals between February and April (summer to autumn), when the photoperiod becomes shorter.

\section{Females}

The female gonad extended from the apex to almost the end of the body whorl (Figs. 1a \& 5a). The ovary was light yellow (ripe) and conspicuous; it was composed of many tubules where oogenesis was taking place (Fig. 5a). Each tubule was surrounded by

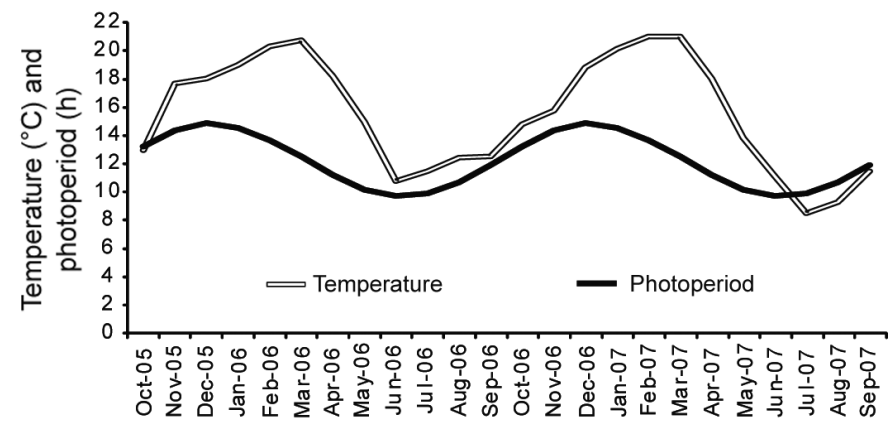

Fig. 4. Mean values of surface seawater temperature $\left({ }^{\circ} \mathrm{C}\right)$ and photoperiod (hours of light) for the study period (October 2005 to September 2007). Data from Red ANTARES (www.iafe.uba.ar/tele/Antares_argentina/) and Servicio de Hidrografía Naval (www.hidro.gov.ar) connective tissue and contained companion cells in close contact with the oocytes.

The female gametogenic cycle was divided into 4 developmental stages: early vitellogenesis, pre-evacuation, evacuation, and resorption. The first stage (early vitellogenesis) was characterized by a larger proportion of oogonia and pre-vitellogenic oocytes (up to about $200 \mu \mathrm{m}$ in diameter) near the tubule walls and the presence of companion cells (Fig. 5b); a few vitellogenic oocytes were found in the lumen (Fig. 5c). In the pre-evacuation stage, the ovary increased in size and the tubules were full of vitellogenic oocytes measuring between $250 \mu \mathrm{m}$ and $1 \mathrm{~mm}$ in diameter (Fig. 5d); oocytes were free in the lumen, ready to be released. In the evacuation stage, most of the oocytes were released but a few of them remained (Fig. 5e); no pre-vitellogenic oocytes were found in the tubule walls. The resorption stage was characterized by empty tubules with a decrease in size and the presence of new oogonia in the tubule walls (Fig. 5f).

The monthly frequency of females in each developmental stage is summarized in Fig. 6. In contrast to males, females showed a fully active gonad and gamete liberation over almost the entire study period. The early-vitellogenesis stage occurred between February and June (summer to autumn). The preevacuation stage took place throughout the study period, except for January and February of both years and March 2006. The evacuation stage continued throughout the study period except for May (2006 and 2007) and February 2006. The largest proportion of individuals ( $\geq 60 \%$ ) at this stage was recorded in spring, between October and December 2005 and September (2006 and 2007), simultaneously with an increase in surface water temperature and photoperiod. The resorption stage extended between January and February of both years (summer) and, in contrast to males, it was absent in some individuals. Fig. 7 shows the monthly frequency of oocyte diameter obtained during the $2 \mathrm{yr}$ study period (from October 2005 to August 2007).

\section{DISCUSSION}

\section{Population structure}

In the studied population of Olivancillaria deshayesiana, total SLs ranged from 16 to $35 \mathrm{~mm}$, with males being significantly larger than females. Specimens smaller than $16 \mathrm{~mm}$ escaped through the net (mesh size: $15 \mathrm{~mm}$ ). The population showed a female:male sex ratio of 1:1.4, with a clear predominance of males. 

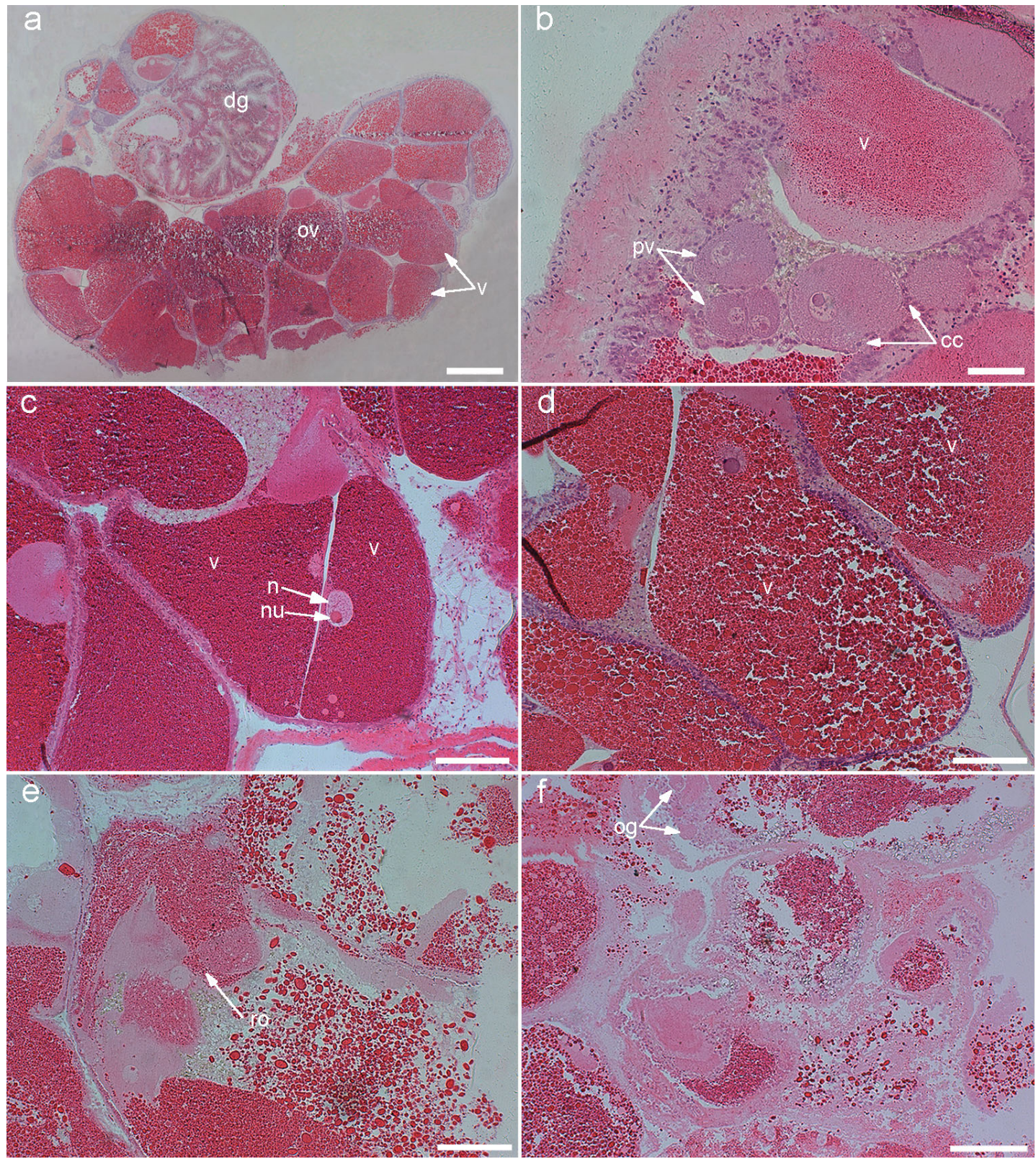

Fig. 5. Olivancillaria deshayesiana. Histology of female gonad at different developmental stages. (a) General view of a mature female ovary (ov) full of vitellogenic oocytes (v) in close contact with the digestive gland (dg). (b,c) Early vitellogenesis: pre-vitellogenic oocytes (pv) surrounded by companion cells (cc) and vitellogenic oocytes (v); note the presence of nucleus (n) and nucleolus (nu). (d) Pre-evacuation: vitellogenic oocytes occupying the entire tubule. (e) Evacuation: tubules almost empty, with residual oocytes (ro). (f) Resorption: empty tubules with new oogonia (og). Scale bars =600 $\mu \mathrm{m}$ (a); $300 \mu \mathrm{m}$ (b); $100 \mu \mathrm{m}$ (c); $200 \mu \mathrm{m}$ (d-f)

This pattern is quite uncommon in gonochoristic gastropods, among which females predominate over males with a male:female sex ratio of up to 1:2 (Feare 1970, McGwynne \& van der Horst 1985, Gibbs et al. 1988, Martel et al. 1986, Olabarria \& Ramirez-Llodra 2004, Narvarte 2006), or with females being at least as frequent as males (Fretter \& Graham 1994, Giménez \& Penchaszadeh 2002, Cledón et al. 2005).
The presence of imposex in Olivancillaria deshayesiana throughout the study period provides evidence of the negative influence of the port of Mar del Plata on the local gastropod population, confirming previous results (Teso \& Penchaszadeh 2009). This is in line with the study of Bigatti et al. (2009), who recorded TBT pollution in the sediments in Mar del Plata. In this study, no histological alterations in 


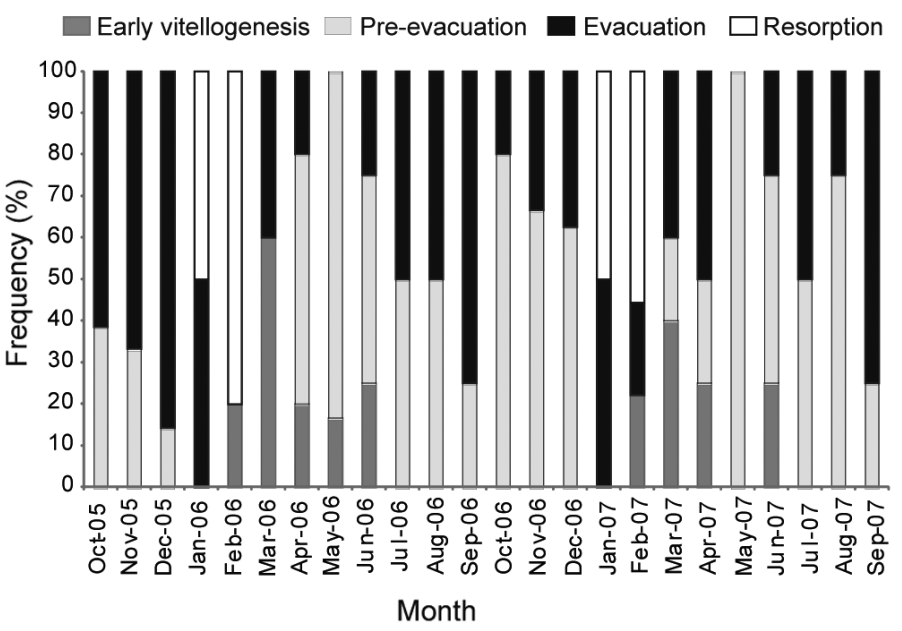

Fig. 6. Olivancillaria deshayesiana. Monthly frequency of different gonad developmental stages of females for the study period (October 2005 to September 2007) gonad structure were observed, and in consequence the gonadal cycle was not affected. Similar results were found by Cledón et al. (2005) in a population of the snail Adelomelon brasiliana in the same area. On the other hand, the neoformation of multiple penises in females indicates that the sensitivity to TBT is higher in $O$. deshayesiana than in other snails from the same area, such as Buccinanops monilifer and $A$. brasiliana, which had lower percentages of imposex and RPSI values (Cledón et al. 2006, Averbuj \& Penchaszadeh 2010).

\section{Gonadal structure and reproductive cycle}

This study represents one of the first reports on the gametogenic cycle in species of the family Olividae, along with the report of Rocha-Barreira (2001). The
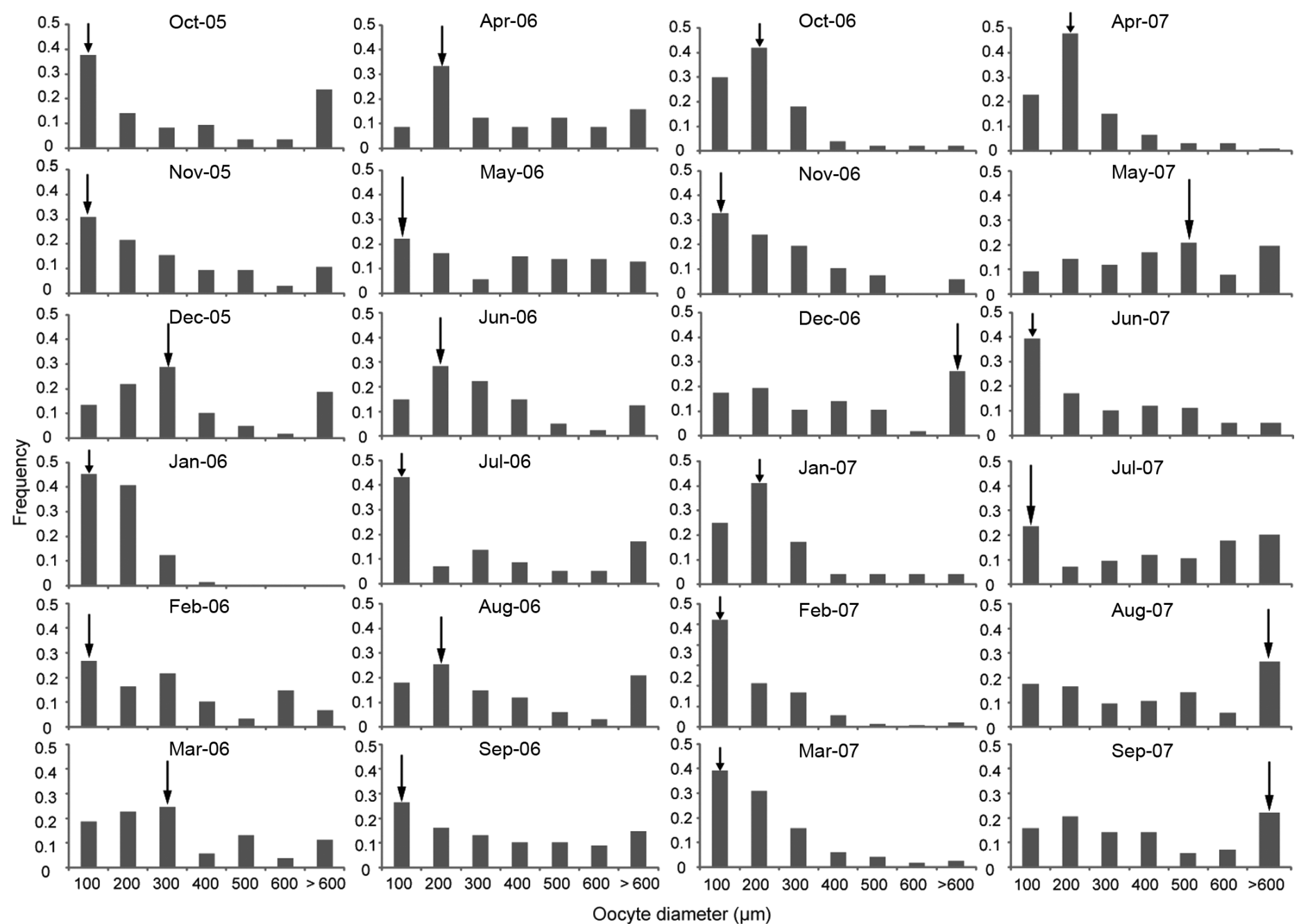

Oocyte diameter $(\mu \mathrm{m})$

Fig. 7. Olivancillaria deshayesiana. Monthly relative frequency of oocyte diameter (October 2005 to September 2007). Arrows indicate the modal monthly oocyte diameter 
general structure of the gonads of Olivancillaria deshayesiana is similar to that of other olivids (Marcus \& Marcus 1959, Rocha-Barreira 2001, Pimenta 2005). Its testis and ovary are of the same color as in $O$. auricularia (Rocha-Barreira 2001) and extend from the apex to almost the end of the body whorl.

\section{Males}

Male reproduction is seasonal, with a major spawning period between spring and early summer (September to January) of both years. This pattern may be related to an increase in seawater temperature and photoperiod, which are important environmental factors regulating gonadal development and spawning in many gastropod species (Fretter \& Graham 1994, Giménez \& Penchaszadeh 2002, Cledón et al. 2005, Bigatti et al. 2008, Penchaszadeh et al. 2009, Arrighetti \& Penchaszadeh 2010, Averbuj \& Penchaszadeh 2010). Males exhibited a pronounced resting period from summer to autumn (February to April), in accordance with a decrease in these variables. From May to June, all individuals underwent a stage of proliferation and growth. Seasonal reproduction in males was also found in Buccinum undatum by Martel et al. (1986) and in Olivancillaria auricularia (as $O$. vesica auricularia) by Rocha-Barreira (2001). However, this pattern is unusual in males of other Neogastropoda species, whose testes seem to produce mature sperm year round without a resting period, e.g. the volutids Zidona dufresnei (Giménez \& Penchaszadeh 2002), Adelomelon brasiliana (Cledón et al. 2005), and A. beckii (Arrighetti \& Penchaszadeh 2010) in Mar del Plata, Odontocymbiola magellanica (Bigatti et al. 2008) and A. ancilla (Penchaszadeh et al. 2009) in Golfo Nuevo, and the nasarid Buccinanops cochlidium in Golfo San José (Averbuj et al. 2010), among others.

\section{Females}

In contrast to males, females were mature and spawning year round, with a major spawning event between September and January (spring to early summer). This period coincided with the major spawning period of males. No females in the stage of proliferation and growth (exclusive presence of oogonia and pre-vitellogenic oocytes in the tubules) were found. The resorption period was short (January to February) and was only observed in some individuals. As a general rule in Caenogastropoda, tropical spe- cies often have extended spawning periods while a seasonal pattern is common in temperate species (Webber 1977). The latter is the case for the volutids Zidona dufresnei (Giménez \& Penchaszadeh 2002) and Adelomelon brasiliana (Cledón et al. 2005) from Argentina and a population of Buccinum undatum from Canada (Martel et al. 1986), among others. However, as observed in the present study, the females of some Caenogastropoda species of temperate areas have a continuous reproduction with different spawning intensities, such as A. beckii (Arrighetti \& Penchaszadeh 2010) and Odontocymbiola magellanica (Bigatti et al. 2008) from Argentina, Olivella biplicata (Edwards 1968) and Nucella emarginata from California (USA), and Nucella lapillus from France (Webber 1977). Moreover, Borzone (1995) reported the occurrence of egg capsules in a population of Olivancillaria deshayesiana from Rio Grande do Sul (Brazil) throughout the year, with higher abundances between August and October. The continuous reproductive activity of females observed in this study is consistent with the continuous occurrence of egg capsules in the population from Brazil (Borzone 1995). This, in turn, reinforces the hypothesis of continuous reproduction.

It was difficult to measure a representative number of vitellogenic oocytes larger than $600 \mu \mathrm{m}$ (ready to be spawned) because only a few of them had a nucleus with nucleolus in the histological preparation of the gonad. This resulted in an underestimation of the frequencies of large oocytes, and therefore the use of oocyte size appears to be unfeasible for determining the reproductive cycle in Olivancillaria deshayesiana and other species showing the same type of reproduction.

\section{General remarks}

The seasonal reproductive activity of males (with a clear resting period) suggests that females store sperm in the seminal receptacle for several months. This same pattern was suggested for Buccinum undatum (Martel et al.1986) and other species (e.g. Fretter \& Graham 1994, Bigatti et al. 2008). The occurrence of egg capsules year round and the development of a single egg of between 800 and $900 \mu \mathrm{m}$ within each egg capsule (Borzone 1995) may indicate an extended period of vitellogenesis during which each female deposits a few egg capsules per year. A similar pattern was reported for Olivancillaria auricularia from southwestern Brazil (Rocha-Barreira 2001). This pattern implies high energetic costs of 
reproduction, explaining the smaller body size of females. Similar observations of body size and reproductive pattern were reported for Olivella biplicata (Edwards 1968).

All individuals sampled in this study were mature, because the sampling method excluded individuals $<16 \mathrm{~mm}$ in SL. According to the von Bertalanffy growth model of Olivancillaria deshayesiana (Arrighetti et al. 2012), mature individuals of $16 \mathrm{~mm}$ in SL correspond to an age of about 1 yr. This result may indicate that this population attains first sexual maturity before other gastropods, such as Haliotis rubra (6 to $7 \mathrm{yr}$; Prince et al. 1988), Buccinum undatum (6 to $7 \mathrm{yr}$; Gendron 1992), Zidona dufresnei (8 to $9 \mathrm{yr}$; Giménez et al. 2004), Adelomelon brasiliana (7 yr; Cledón et al. 2008), and Odontocymbiola magellanica (8 yr; Bigatti et al. 2007).

Acknowledgements. Special thanks are due to the late fisherman J. L. Ungarelli for capturing most of the samples. This work was partially supported by grants from the PADI Foundation in 2007, the Lerner Gray Memorial Fund (AMNH) to V.T. in 2007, Buenos Aires University (UBACyT X 117), the National Agency for Scientific and Technical Promotion, Argentina (PICTR 1869 and PICT 942), and the Consejo Nacional de Investigaciones Científicas y Técnicas, Argentina (CONICET, PIP 2788).

\section{LITERATURE CITED}

Arrighetti F, Penchaszadeh PE (2010) Gametogenesis, seasonal reproduction and imposex of Adelomelon beckii (Neogastropoda: Volutidae) in Mar del Plata, Argentina. Aquat Biol 9:63-75

Arrighetti F, Teso V, Brey T, Mackensen A, Penchaszadeh PE (2012) Age and growth of Olivancillaria deshayesiana (Gastropoda: Olividae) in the southwestern Atlantic ocean. Malacologia 55 (in press)

> Averbuj A, Penchaszadeh P (2010) On the reproductive biology and impact of imposex in a population of Buccinanops monilifer from Mar del Plata, Argentina. J Mar Biol Assoc UK 90:729-734

Averbuj A, Bigatti G, Penchaszadeh P (2010) Gametogenic cycle and size at first maturity of the Patagonic edible snail Buccinanops cochlidium from Argentina. Mar Biol 157:2229-2240

> Bigatti G, Penchaszadeh PE, Cledón M (2007) Age and growth in Odontocymbiola magellanica (Gastropoda: Volutidae) from Golfo Nuevo, Patagonia, Argentina. Mar Biol 150:1199-1204

Bigatti G, Marzinelli EM, Penchaszadeh PE (2008) Seasonal reproduction and sexual maturity in Odontocymbiola magellanica (Neogastropoda, Volutidae). Invertebr Biol 127:314-326

Bigatti G, Primost M, Cledón M, Averbuj A and others (2009) Contamination by TBT and imposex biomonitoring along $4700 \mathrm{~km}$ of Argentinean shoreline (SW Atlantic: from $38^{\circ} \mathrm{S}$ to $\left.54^{\circ} \mathrm{S}\right)$. Mar Pollut Bull 58:695-701

Borzone CA (1995) Ovicápsulas de Prosobranquios (Mol- lusca: Gastropoda) de una playa arenosa expuesta del sur del Brasil. Iheringia Ser Zool 79:47-58

Cledón M, Arntz W, Penchaszadeh PE (2005) Gonadal cycle in an Adelomelon brasiliana (Neogastropoda: Volutidae) population of Buenos Aires province, Argentina. Mar Biol 147:439-445

Cledón M, Theobald N, Gerwinski W, Penchaszadeh P (2006) Imposex and organotin compounds in marine gastropods and sediments from the Mar del Plata coast, Argentina. J Mar Biol Assoc UK 86:751-755

Cledón M, Arntz W, Penchaszadeh PE (2008) Size and age at sexual maturity in Adelomelon brasiliana (Neogastropoda: Volutidae) off Argentina. J Mar Biol Assoc UK 147: $447-452$

Edwards DC (1968) Reproduction in Olivella biplicata. Veliger 10:297-304

Feare CJ (1970) The reproductive cycle of the dog whelk (Nucella lapillus). Proc Malacol Soc Lond 39:125-137

Fretter V, Graham A (1994) British prosobranch molluscs: their functional anatomy and ecology. The Ray Society of London, London

Gendron L (1992) Determination of the size at sexual maturity of the waved whelk Buccinum undatum Linnaeus, 1758, in the Gulf of St. Lawrence, as a basis for the establishment of a minimum catchable size. J Shellfish Res 11:1-7

Gibbs PE, Bryan GW (1994) Biomonitoring of tributyltin (TBT) pollution using the imposex response of neogastropod molluscs. In: Kramer KJM (ed) Biomonitoring of coastal waters and estuaries. CRC Press, Boca Raton, FL, p 205-226

Gibbs PE, Pascoe PL, Burt GR (1988) Sex change in the female dog-whelk, Nucella lapillus, induced by tributyltin from antifouling paints. J Mar Biol Assoc UK 68: 715-731

Giménez J, Penchaszadeh PE (2002) Reproductive cycle of Zidona dufresnei (Caenogastropoda: Volutidae) from the southwestern Atlantic Ocean. Mar Biol 140:755-761

Giménez J, Brey T, Mackensen A, Penchaszadeh PE (2004) Age, growth, and mortality of the prosobranch Zidona dufresnei (Donovan, 1823) in the Mar del Plata area, south-western Atlantic Ocean. Mar Biol 145:707-712

Guerrero RA, Piola AR (1997) Masas de agua en la plataforma continental. In: Boschi EE (ed) El mar y sus recursos pesqueros. Instituto Nacional de Investigación y Desarrollo Pesquero (INIDEP), Mar del Plata, p 107-118

Marcus E, Marcus E (1959) Studies on Olividae. Bol Univ Sao Paolo Fac Filos Cienc Letr 232:99-188

- Martel A, Larrivée DH, Himmelman JH (1986) Behaviour and timing of copulation and egg-laying in the neogastropod Buccinum undatum L. J Exp Mar Biol Ecol 96:27-42

McGwynne LE, van der Horst G (1985) Patterns of reproduction in three sandy beach whelks of the genus Bullia Griffith. J Molluscan Stud 51:190-197

Narvarte MA (2006) Biology and fishery of the whelk Buccinanops globulosum (Kiener, 1834) in northern coastal waters of the San Matías Gulf (Patagonia, Argentina). Fish Res 77:131-137

Olabarria C, Ramirez-Llodra E (2004) Reproductive strategies of two deep-sea gastropod species from the Porcupine Seabight (Northeast Atlantic). Mar Biol 145: 541-549

Penchaszadeh PE, Averbuj A, Cledón M (2001) Imposex in gastropods from Argentina (South-West Atlantic). Mar Pollut Bull 42:790-791

Penchaszadeh P, Sanchez-Antelo C, Zabala MS, Bigatti G 
(2009) Reproduction and imposex in the edible snail Adelomelon ancilla from northern Patagonia, Argentina. Mar Biol 156:1929-1939

Pimenta DP (2005) Morfología comparada e relacionamiento filogenético da familia Olividae Latreille, 1825 (Mollusca: Gastropoda: Neogastropoda). PhD thesis, Universidade Federal do Rio de Janeiro

Prince JD, Sellers TL, Ford WB, Talbot SR (1988) Recruitment, growth, mortality and population structure in a southern Australian population of Haliotis rubra (Mollusca: Gastropoda). Mar Biol 100:75-82

Rocha-Barreira CA (2001) Biologia de Olivancillaria vesica auricularia (Lamarck, 1810) (Mollusca, Gastropoda, Olividae) na Praia do Cassino, Rio Grande, Rio Grande do Sul Brasil. PhD thesis, Fundação Universidade Federal do Rio Grande

Scelzo MA, Martinez Arca J, Lucero NM (2002) Diversidad,

Editorial responsibility: Riccardo Cattaneo-Vietti, Genova, Italy densidad y biomasa de la macrofauna componente de los fondos de pesca 'camarón-langostino', frente a Mar del Plata, Argentina (1998-1999). Rev Investig Desarro Pesq 15:43-65

Sokal RR, Rohlf FJ (1995) Biometry: the principles and practice of statistics in biological research, 3rd edn. WH Freeman, New York, NY

Teso V, Pastorino G (2011) A revision of the genus Olivancillaria (Mollusca: Olividae) from the southwestern Atlantic. Zootaxa 2889:1-34

Teso SV, Penchaszadeh PE (2009) Beach filling and imposex in Olivancillaria deshayesiana (Mollusca: Gastropoda: Olividae) from the coast of Mar del Plata, Argentina. J Mar Biol Assoc UK 88:557-562

Webber HH (1977) Gastropoda: Prosobranchia. In: Gieses $\mathrm{AC}$, Pearse JS (eds) Reproduction of marine invertebrates. Academic Press, New York, NY, p 1-97

Submitted: October 24, 2011; Accepted: January 2, 2012

Proofs received from author(s): April 26, 2012 